\title{
Genome-wide identification of F-box proteins in Macrophomina phaseolina and comparison with other fungus
}

Md. Abu Sadat ${ }^{*}$ (D, Md. Wali Ullah, Kazi Khayrul Bashar, Quazi Md. Mosaddeque Hossen, Md. Zablul Tareq and Md. Shahidul Islam

\begin{abstract}
Background: In fungi, like other eukaryotes, protein turnover is an important cellular process for the controlling of various cellular functions. The ubiquitin-proteasome pathway degrades some selected intracellular proteins and Fbox proteins are one of the important components controlling protein degradation. F-box proteins are well studied in different model plants however, their functions in the fungi are not clear yet. This study aimed to identify the genes involved in protein degradation for disease development in the Macrophomina phaseolina fungus.

Results: In this research, in silico studies were done to understand the distribution of F-box proteins in pathogenic fungi including Macrophomina phaseolina fungus. Genome-wide analysis indicates that M. phaseolina fungus contained thirty-one F-box proteins throughout its chromosomes. In addition, there are 17, 37, 16, and 21 F-box proteins have been identified from Puccinia graminis, Colletotrichum graminicola, Ustilago maydis, and Phytophthora infestans, respectively. Analyses revealed that selective fungal genomes contain several additional functional domains along with F-box domain. Sequence alignment showed the substitution of amino acid in several F-box proteins; however, gene duplication was not found among these proteins. Phylogenetic analysis revealed that Fbox proteins having similar functional domain was highly diverse form each other showing the possibility of various function. Analysis also found that MPH_00568 and MPH_05531 were closely related to rice blast fungus F-box protein MGG_00768 and MGG_13065, respectively, may play an important role for blast disease development.

Conclusion: This genome-wide analysis of F-box proteins will be useful for characterization of candidate F-box proteins to understand the molecular mechanisms leading to disease development of M. phaseolina in the host plants.

Keywords: F-box proteins, M. phaseolina, Disease development
\end{abstract}

\footnotetext{
*Correspondence: sadat@snu.ac.kr

Basic and Applied Research on Jute Project, Bangladesh Jute Research

Institute, Manik Mia Avenue, Dhaka 1207, Bangladesh
}

\section{Springer Open}

(c) The Author(s). 2021 Open Access This article is licensed under a Creative Commons Attribution 4.0 International License, which permits use, sharing, adaptation, distribution and reproduction in any medium or format, as long as you give appropriate credit to the original author(s) and the source, provide a link to the Creative Commons licence, and indicate if changes were made. The images or other third party material in this article are included in the article's Creative Commons licence, unless indicated otherwise in a credit line to the material. If material is not included in the article's Creative Commons licence and your intended use is not permitted by statutory regulation or exceeds the permitted use, you will need to obtain permission directly from the copyright holder. To view a copy of this licence, visit http://creativecommons.org/licenses/by/4.0/. 


\section{Background}

Protein turnover is the balance between protein synthesis and protein degradation. This process is an important regulator of functioning of the different cellular processes including cell cycle, metabolic control, physical development, and various signal transduction pathways [1, 2]. Protein turnover processes are the same in different cells, however highly different in the aspect of turnover control and regulation [3]. Proteins serve a variety of functions within cells and also interact with other proteins, lipids carbohydrates, and even with DNA [4-7]. Most plants and microorganisms can synthesize proteins inside the cell but animals need to take protein through their daily meal [8]. Protein levels are an important regulator of eukaryotic cell development [9]. Protein synthesis is concluded either by biosynthesis or chemical synthesis procedure.

Proteolysis is the breakdown of protein into smaller polypeptides or amino acids. It is a highly specific process where proteins are hydrolyzed to their specific amino acids [1]. In this process, a diverse group of enzymes and designated proteases is involved. In eukaryotic cells, two major pathways are involved in protein degradation: the lysosomal proteolysis pathway and ubiquitin-proteasome pathway [10]. In the lysosomal proteolysis pathway, cell uptake degraded protein by lysosomes through a nonselective process, but it may become selective during starvation especially under carbon and nitrogen starvation condition [11]. Proteins which are degraded in lysosomal proteolysis pathway are commonly long lived, but their necessities and number are very low. However, most of the intracellular proteins are degraded by another pathway, namely the ubiquitin-proteasome pathway. This pathway is highly specific and targets cytosolic and nuclear proteins for rapid degradation $[10,12]$.

Ubiquitin is a regulatory protein that is highly conserved in all eukaryotes. Protein degradation under the ubiquitin-proteasome pathway involves three major steps: (i) ATP-dependent activation of ubiquitin by E1 enzyme (ubiquitin-activating enzyme), (ii) transfer of activated ubiquitin to E2 (ubiquitin-conjugating enzyme), and (iii) transfer of ubiquitin to the protein to be degraded by E3 complex (ubiquitin protein ligase) [13]. Polyubiquitinated proteins are recognized by the $26 \mathrm{~S}$ proteasome in which the targets are specifically degraded. E3 ligases are the F-box protein which form a subunit of SCF complex (Skp, Cullin and F-box containing) and confer specificity for a substrate to be degraded [12]. Studies showed that Fbox proteins contain a novel motif, linked to cyclin $\mathrm{F}$ along with cell cycle regulators of yeast Cdc4p and Skp2p to Skp1p, which are major components of E3 ligase [14].

The F-box protein was first described as cyclin $F$ in human genome; however, a large number of this protein family exists in different model organisms having various functions [15]. F-box proteins were identified as SCF components; they function as non-SCF complexes, too [16-18]. The number of F-box proteins are greatly varying in eukaryotic organisms and found to be comparatively higher in plants due to diverse functions including physical growth and development, floral organogenesis, senescence, and pathogen resistance [19]. In hemibiotrophic fungus Magnaporthe oryzae, F-box protein is crucial for conidiogenesis, fungal growth and development, and finally for virulence [20-22]. In addition, Fbox proteins were reported to be involved in sexual reproduction, morphogenesis and for disease-causing ability in human pathogen Cryptococcus neoformans, Aspergillus nidulans, and in Candida albicans [1, 23, 24]. The understanding of SCF E3 ligases has largely come from extensive studies in two model yeasts, $S$. cerevisiae and Schizosaccharomyces pombe. S. cerevisiae has at least 20 proteins containing an F-box domain, and several have been well studied, including glucose repression resistant 1 (Grr1) [15]. Despite extensive studies in both model yeasts, very limited studies of SCF E3 ligases have been reported in other fungi. Recent studies on the function of F-box proteins in pathogenic fungi have revealed that SCF E3 ligases are required for fungal virulence. Because of the proven therapeutic potential of the ubiquitin-proteasome pathway for human diseases [25], it would be very important to understand the molecular basis of how this pathway regulates fungal virulence.

Jute is the second most important natural fiber crop after cotton in Bangladesh and called the golden fiber of Bangladesh because of earning a lot of foreign currency [26]. Recently, raw jute and jute product has been considered as the second foreign earning of Bangladesh [27]. However, jute is affected by several biotic and abiotic stresses throughout its growing season and causing yield loss [28]. Macrophomina phaseolina is one of the most important pathogens of jute plant causing stem rot disease leading to yield loss up to $30 \%$ [29]. This pathogen has more than 500 hosts including food crops, pulse crops, jute, cotton, and also other crops. This fungus can solely reduce up to $30 \%$ jute yield among the total production loss due to fungal diseases and others [29]. Consider the economic importance of this fungus genomic information has been carried out to understand its high survivability and disease-causing ability.

Based on the importance of F-box protein in eukaryotes, we have systematically performed the bioinformatic analysis to identify the gene structure, sequence alignment, phylogenetic relationship, exon-intron structures, domain of Fbox protein in the stem rot fungus $M$. phaseolina. These results provide an essential understanding of F-box protein in $M$. phaseolina and constitute a strong foundation for further investigation in regulation of fungal virulence, 
which may lead to novel approaches in developing new antifungal agents.

\section{Methods}

Identification of F-box proteins from different fungi

To identify the F-box protein sequences in M. phaseolina, their protein and genome sequence were downloaded from the website of Basic and Applied Research on Jute Project (BARJ) (http://www.jutegenome.org/gb2/gbrowse/mph/) and NCBI database (https://www.ncbi.nlm.nih.gov/ bioproject?term=PRJNA78845). And another online database, comparative fungal genomic platform (CFGP 2.0) (http://cfgp.riceblast.snu.ac.kr) was used for the identification of F-box proteins from the selected fungal genomes [30]. In this analysis, a total of 25 fungal genomes (Table 1) were used where Inter Pro domain (IPR001810; IPR006 527; IPR007397; IPR012885; IPR013187; IPR017451, and IPR022364) was used as reference for this search. The E-value threshold was selected at $10^{-3}$ to get the entire possible F-box protein candidates.

\section{Basic structure and localization}

Information of protein length was gathered from the NCBI database (http://www.ncbi.nlm.nih.gov). General feature format (GFF) data were used to identify exon-intron structures of all F-box domain-containing proteins from the M. phaseolina fungus with the help of online software Gene Structure Display Server 2.0 (http://gsds.cbi.pku.edu. cn/). Online-based software WoLF PSORT was applied to predict the probable localization of all thirty-one F-box box proteins [32]. Different domains were identified and analyzed with the online software SMART (http://smart. embl.de/) and Pfam (https://pfam.xfam.org/).

Table 1 Presence of F-box proteins in different economically important fungi and plants

\begin{tabular}{|c|c|c|c|c|}
\hline Species & Kingdom & Lifestyle & No. of F-box protein (total gene) & Source \\
\hline Blumeria graminis & Fungi & Biotroph & $24(6470)$ & This study \\
\hline Puccinia graminis & Fungi & Biotroph & $17(20,567)$ & This study \\
\hline Melampsora laricis-populina & Fungi & Biotroph & $19(16,694)$ & This study \\
\hline Magnaporthe oryzae & Fungi & Hemibiotroph & $24(12,991)$ & Shi et al. [21] \\
\hline Colletotrichum graminicola & Fungi & Hemibiotroph & $37(12,022)$ & This study \\
\hline Ustilago maydis & Fungi & Hemibiotroph & $16(6689)$ & This study \\
\hline Mycosphaerella graminicola & Fungi & Hemibiotroph & $48(10,952)$ & This study \\
\hline Phytophthora infestans & Chromista & Hemibiotroph & $21(22,658)$ & This study \\
\hline Macrophomina phaseolina & Fungi & Necrotroph & $31(14,249)$ & This study \\
\hline Fusarium graminearum & Fungi & Necrotroph & $63(13,321)$ & Liu et al. [1] \\
\hline Fusarium oxysporum & Fungi & Necrotroph & $53(17,701)$ & Liu et al. [1] \\
\hline Botrytis cinerea & Fungi & Necrotroph & $40(16,448)$ & Liu et al. [1] \\
\hline Cryptococcus neoformans & Fungi & Animal pathogen & 19 (6431) & Liu et al. [1] \\
\hline Histoplasma capsulatum & Fungi & Animal pathogen & $29(8038)$ & This study \\
\hline Coccidioides immitis & Fungi & Animal pathogen & $38(10,457)$ & This study \\
\hline Candida albicans & Fungi & Animal pathogen & $21(6185)$ & Liu et al. [1] \\
\hline Aspergillus fumigatus & Fungi & Animal pathogen & 40 (9929) & This study \\
\hline Aspergillus nidulans & Fungi & Saprotroph & $55(10,658)$ & Liu et al. [1] \\
\hline Neurospora crassa & Fungi & Saprotroph & 35 (9935) & This study \\
\hline Podospora anserina & Fungi & Saprotroph & $40(10,956)$ & This study \\
\hline Saccharomyces cerevisiae & Fungi & Saprotroph & $11(6713)$ & This study \\
\hline Schizosaccharomyces pombe & Fungi & Saprotroph & $12(5058)$ & This study \\
\hline Phanerochaete chrysosporium & Fungi & Saprotroph & $60(13,602)$ & This study \\
\hline Serpula lacrymans & Fungi & Saprotroph & $39(14,495)$ & This study \\
\hline Laccaria bicolor & Fungi & Symbiotic & $95(23,130)$ & This study \\
\hline Arabidopsis thaliana & Viridiplantae & N/A & $568(35,386)$ & Kuroda et al. [31] \\
\hline Oryza sativa japonica & Viridiplantae & $\mathrm{N} / \mathrm{A}$ & $687(67,393)$ & Jain et al. [2] \\
\hline Cicer arietinum & Viridiplantae & N/A & $285(28,269)$ & Gupta et al. [3] \\
\hline
\end{tabular}


Sequence alignment and chromosomal mapping of F-box proteins

Protein sequences were collected from two different databases (http://www.ncbi.nlm.nih.gov and http://cfgp. riceblast.snu.ac.kr), and those sequences were aligned using Clustal Omega software (https://www.ebi.ac.uk/ Tools/msa/clustalo/). The physical locations of Macrophomina phaseolina F-box proteins on respective chromosomes/ scaffolds were identified using BLASTN search against the local Macrophomina phaseolina database as the Macrophomina phaseolina was not assembled at chromosome-scale so assembled sequences in the form of scaffolds were used for chromosomal mapping. The starting position of each protein was shown on the chromosome or scaffolds.

\section{Gene ontology (GO) analysis}

Gene ontology (GO) annotation of F-box proteins for understanding the biological processes, cellular components and molecular functions were done through Blast2GO program (https://www.biobam.com/download-omicsbox/).

\section{Phylogenetic analysis}

The full-length amino acid sequences of putative F-box proteins of stem rot fungus $M$. phaseolina, and published F-box proteins from different fungal organisms were collected from the CFGP 2.0 (http://cfgp.riceblast. snu.ac. $k r$ ) [30]. In order to understand the relationship among the F-box proteins in $M$. phaseolina and the selective fungal organism, a phylogenetic tree was constructed by MEGA6 software. Initially, multiplesequence alignment of abovementioned fungal species of F-box protein sequences were created using the ClustalW tool in MEGA6, and then according to the alignment file, a phylogenetic tree was generated using the neighborjoining (NJ) method [33] inferred from 1000 bootstrap replicates with other default parameter.

\section{Results}

Identification of F-box proteins in different fungi

Members of the F-box protein family consists of a large number of proteins having the F-box domain as a signature. To identify the F-box proteins from different economically important fungi including stem rot fungus Macrophomina phaseolina several InterPro domains were used. In this analysis, the F-box protein from model plants Arabidopsis thaliana, Cicer arietinum, Oryzae sativa, and model fungus rice blast fungus (Magnaporthe oryzae) were also added for the comparison analysis with the F-box proteins from the identified fungal genomes [2, 13, 22, 31]. The genome-wide search found great variations of fungal F-box proteins along with plants where thirty one F-box domain-containing protein was found in jute stem rot fungus $M$. phaseolina genome (Table 1 and Table S1). Saccharomyces cerevisiae, Schizosaccharomyces pombe, Ustilago maydis, and Puccinia graminis contain 11, 12, 16, and 17, respectively, which were lower in number, whereas Fusarium graminearum, Phanerochaete chrysosporium, and Aspergillus nidulans contain a higher number of F-box protein (Table 1). Domain analysis detected several other functional domains like WD40, LRR, and ankyrin along with F-box domain in the M. phaseolina fungus (Fig. 1). This result might indicate the interacting protein variations in the $M$. phaseolina fungus.

\section{Basic structure and chromosomal distribution of $M$. phaseolina F-box proteins}

Protein structures provide the possible function of that particular protein as well as indicate the origin of that particular gene in a genome. To predict the probable functions of F-box proteins, basic structure was analyzed and summarized in Table 2. Analysis found that $>50 \%$ of the identified F-box proteins did not have any intron in their protein structure. In addition, another $23 \%$ protein contained two exons and one intron in their protein sequences. It was also found that two proteins namely MPH_10780 and MPH_12786 had eight and twelve exons, respectively; however, these two proteins did not have the highest protein length among the rest of the Fbox proteins. MPH_00738 protein showed the highest protein length having only four exons and three introns in the protein structure (Table 2 and Figure S1). Around $55 \%$ and $33 \%$ F-box proteins were found to be localized in the cytoplasm and nucleus, respectively. However, only two proteins were predicted to localize in the mitochondria and endoplasmic reticulum (ER), respectively. From the localization analysis, it was confirmed that most of the F-box proteins were localized inside the cell, and it will help to design specific antifungal chemicals. Chromosomal locations of the F-box proteins were determined using the draft genome sequences of Macrophomina phaseolina [29]. Thirty [30] F-box proteins were located on nine (09) different chromosomes (Fig. 2). Chromosomal position of MPH_00738 was not found, and chromosomes 8 and 9 were not found to contain any F-box protein. From this result, no cluster of F-box protein was observed, and it indicated that gene duplication event might not have occurred for this protein family in Macrophomina phaseolina.

\section{Sequence alignment of $M$. phaseolina F-box proteins}

To gain the extensive understanding of F-box proteins in the jute stem rot fungus $M$. phaseolina genome, amino acids of all thirty-one proteins were aligned using Clustal Omega (https://www.ebi.ac.uk/Tools/msa/ clustalo/). Alignment analysis found very low amino acid sequence similarities among the F-box proteins of $M$. 


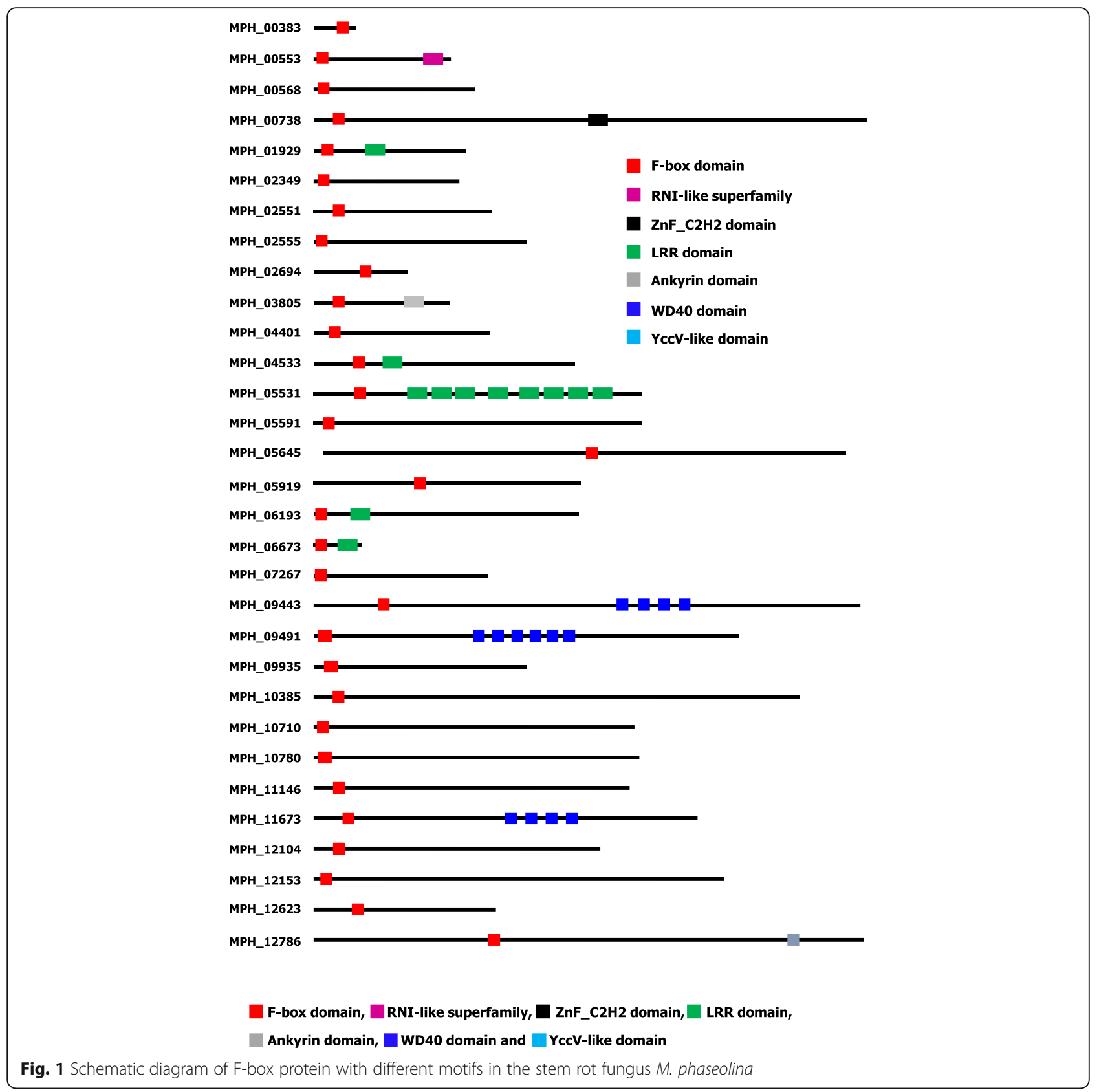

phaseolina except the three amino acids leucine (L), proline (P), and glutamic acid (E) (Fig. 3). However, MPH_09443 proteins did not contain either leucine (L) or proline $(\mathrm{P})$, but solely contained glutamic acid (E), and $\mathrm{MPH} \_12623$ proteins had only proline $(\mathrm{P})$, and the other two, leucine $(\mathrm{L})$ and glutamic acid $(\mathrm{E})$, were absent in the F-box domain (Fig. 3). It was also observed that leucine $(\mathrm{L})$ replaced with isoleucine $(\mathrm{I})$, methionine $(\mathrm{M})$, tyrosine $(\mathrm{Y})$, and proline $(\mathrm{P})$ changed with alanine $(\mathrm{A})$, serine $(\mathrm{S})$, and leucine $(\mathrm{L})$ in several proteins. However, glutamic acid (E) only altered with the aspartic acid (D) in three F-box proteins. This might be due to the point mutation in the nucleic acid of these proteins in the $M$. phaseolina fungus. BLAST results found very low sequence coverage (36\% or less) among the F-box proteins with default e-value (Table S2), pointing that the F-box proteins of Macrophomina phaseolina fungus were not duplicated and those are independent proteins.

\section{Classification of $M$. phaseolina F-box proteins}

Based on the presence of different functional domains along with F-box domain, F-box proteins of $M$. phaseolina fungus were classified. For this analysis, F-box 
Table 2 Basic information of F-box protein in the stem rot fungus Macrophomina phaseolina

\begin{tabular}{|c|c|c|c|c|c|}
\hline Gene locus & Nucleotide size & Protein size & Exon & Intron & Localization \\
\hline MPH_00383 & 360 & 120 & 1 & 0 & Cytoplasmic \\
\hline MPH_00553 & 1191 & 397 & 2 & 1 & Cytoplasmic \\
\hline MPH_00568 & 1389 & 463 & 1 & 0 & Cytoplasmic \\
\hline MPH_00738 & 4842 & 1614 & 4 & 3 & Nuclear \\
\hline MPH_01929 & 1338 & 446 & 1 & 0 & Cytoplasmic \\
\hline MPH_02349 & 1278 & 426 & 1 & 0 & Cytoplasmic \\
\hline MPH_02551 & 1560 & 520 & 4 & 3 & Cytoplasmic \\
\hline MPH_02555 & 1857 & 619 & 3 & 2 & Cytoplasmic \\
\hline MPH_02694 & 825 & 275 & 1 & 0 & Nuclear \\
\hline MPH_03805 & 1194 & 398 & 1 & 0 & Cytoplasmic \\
\hline MPH_04401 & 1536 & 512 & 1 & 0 & Cytoplasmic \\
\hline MPH_04533 & 1680 & 560 & 5 & 4 & Cytoplasmic \\
\hline MPH_05531 & 2112 & 704 & 1 & 0 & Nuclear \\
\hline MPH_05591 & 984 & 328 & 3 & 2 & Cytoplasmic \\
\hline MPH_05645 & 3387 & 1129 & 1 & 0 & Cytoplasmic \\
\hline MPH_05919 & 1707 & 569 & 2 & 1 & Nuclear \\
\hline MPH_06193 & 1152 & 384 & 2 & 1 & Cytoplasmic \\
\hline MPH_06673 & 339 & 113 & 1 & 0 & Nuclear \\
\hline MPH_07267 & 1113 & 371 & 1 & 0 & Cytoplasmic \\
\hline MPH_09443 & 3528 & 1176 & 1 & 0 & Nuclear \\
\hline MPH_09491 & 1872 & 624 & 1 & 0 & Nuclear \\
\hline MPH_09935 & 924 & 308 & 1 & 0 & Cytoplasmic \\
\hline MPH_10385 & 2154 & 718 & 2 & 1 & Mitochondrial \\
\hline MPH_10710 & 1407 & 469 & 2 & 1 & Nuclear \\
\hline MPH_10780 & 1455 & 485 & 8 & 7 & Nuclear \\
\hline MPH_11146 & 1413 & 471 & 1 & 0 & Nuclear \\
\hline MPH_11673 & 1695 & 565 & 2 & 1 & Mitochondrial \\
\hline MPH_12104 & 1263 & 421 & 3 & 2 & Extracellular \\
\hline MPH_12153 & 1809 & 603 & 2 & 1 & Extracellular \\
\hline MPH_12623 & 798 & 266 & 1 & 0 & Cytoplasmic \\
\hline MPH_12786 & 2415 & 805 & 12 & 11 & Cytoplasmic \\
\hline
\end{tabular}

proteins were analyzed using the online software SMAR $\mathrm{T}$ (http://smart.embl.de/) and Pfam (https://pfam.xfam. org/). Analysis found that five major subfamilies where nineteen proteins contained only F-box domain and did not have any other functional domain in their $\mathrm{C}$ terminal region (Fig. 4). In addition, five proteins and three proteins contained additional leucine-rich repeats (LRR) and WD40 repeats, respectively along with the both F-box domain. Moreover, ankyrin repeat was found as an additional functional domain with the F-box domain in one protein namely $\mathrm{MPH}_{-}$ 03805. Three proteins (MPH_00553, MPH_00738, and $\mathrm{MPH}$ _12153) contained 3 different additional domains like RNI-like, $\mathrm{ZnF}-\mathrm{C}_{2} \mathrm{H}_{2}$, and YccV-like along with Fbox domain (Table S1). However, no protein was found with an additional domain of unknown function as commonly found in F-box protein of plants genome. This classification might indicate the protein-protein interaction of the additional domain for disease development in $M$. phaseolina. A gene ontology analysis was also carried out to predict the possible functions of Macrophomina phaseolina F-box proteins. Analysis found that most of the F-box proteins (28 proteins) involved protein binding rather than molecular function, biological process, and cellular component (Table S3). 


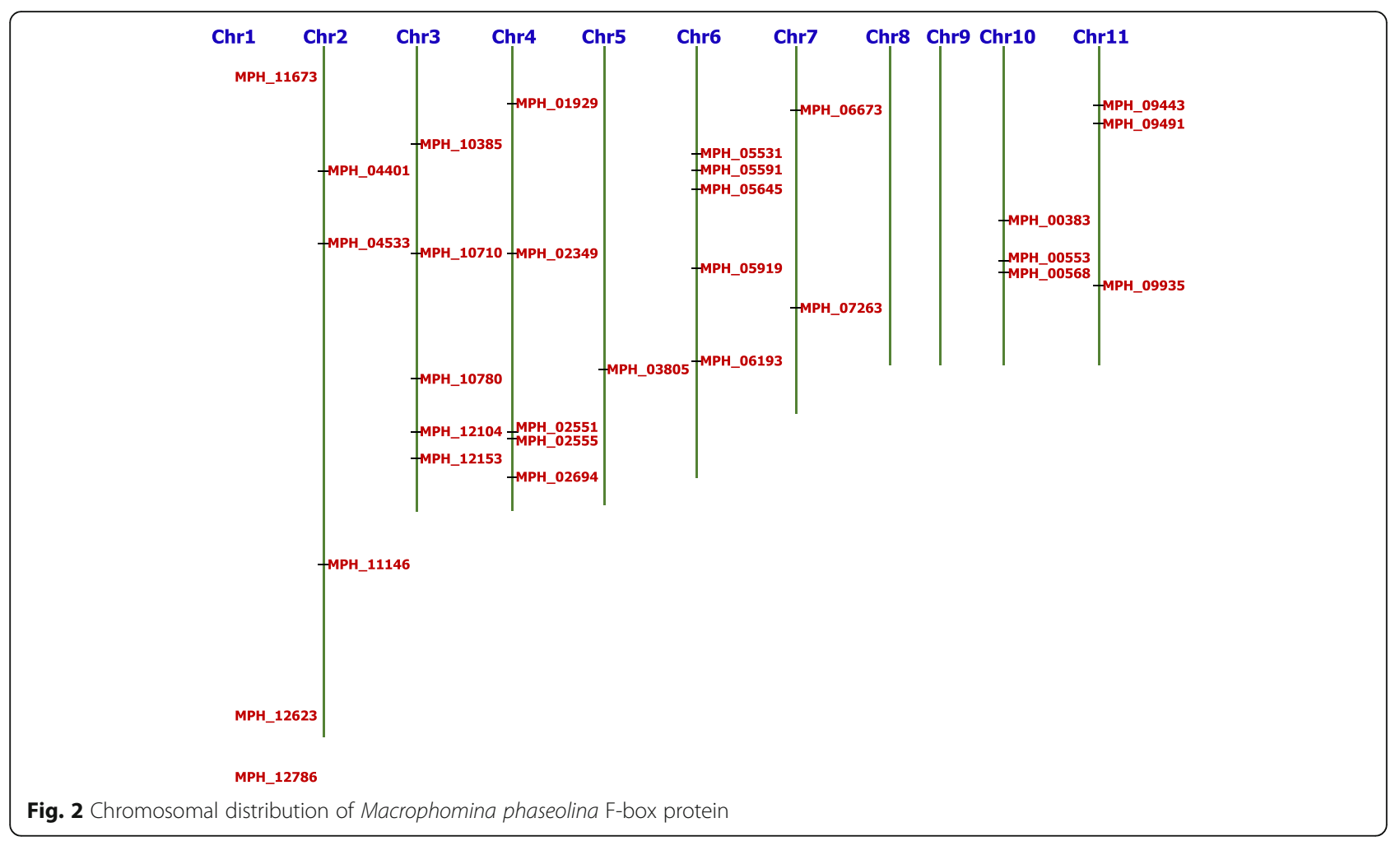

\section{Phylogenetic analysis of F-box proteins}

By using protein sequences, phylogenetic tree was constructed to understand the relationship of F-box proteins in different phytopathogenic fungus. The phylogenetic tree was made through the neighborjoining approach through MEGA 6.0. It has been found that most of the F-box proteins were highly diverse from one protein to another (Fig. 5). M. phaseolina genome contains five F-box protein namely MPH_04533, MPH_06673, MPH_01929, MPH_06193, and MPH_05531 having leucine-rich repeat (LRR); however, MPH_05531 only showed a close relationship with yeast Grr1, rice blast fungus MoGrr1, and powdery mildew pathogen B. graminis (estExt fgenesh2 pg. $C$ 570056), WD40 repeat containing F-box proteins were mostly found in a similar place in the phylogenic tree; however, WD40 repeat containing F-box proteins of M. phaseolina seemed to diverse from them and found far away from the major subclade of WD40 domain-containing F-box proteins (Fig. 5). Among the four fungal species, M. phaseolina and M. oryzae had one ankyrin repeat-containing F-box protein in each fungus, but they are phylogenetically distant and present in different places in the tree indicating the possibility of interaction with different proteins. From the phylogenetic tree, it can also be predicted that sequence diversity of those proteins may lead to diverge functions in fungi.

\section{Comparison of $M$. phaseolina F-box proteins with other phytopathogenic fungal F-box proteins}

It has been reported that protein families vary from organism to organism, and this might help to predict their involvement of physiological process as well as evolution of that particular protein families. In this analysis, F-box proteins of fungi having different lifestyles, and plants were also included to understand the distribution of $\mathrm{F}$ box proteins in different organisms.

Proportion of contained F-box proteins in most selected fungal genomes ranging from 10 to $49 \%$ in Phytophthora infestans and Histoplasma capsulatum, respectively (Fig. 6). It is quite interesting that a proportion of F-box proteins in the kingdom Viridiplantae were much higher than the selected fungi used in this study (Table 1). This result might suggest that plants require more F-box proteins for performing various physiological processes to complete their full life cycle, whereas, a lower number of proteins in fungi indicate their importance during the disease development process in the host. Analysis also revealed that presence of F-box proteins had no relationship with the lifestyles (biotrophic, hemibiotrophic, and necrotrophic nature) and also with the host range of selected fungi used in this study. Symbiotic fungus Laccaria bicolor genome contained the highest number of F-box proteins compared with the rest of the fungi; however, the proportions were almost similar with the proportion of other three fungi namely, Mycosphaerella 


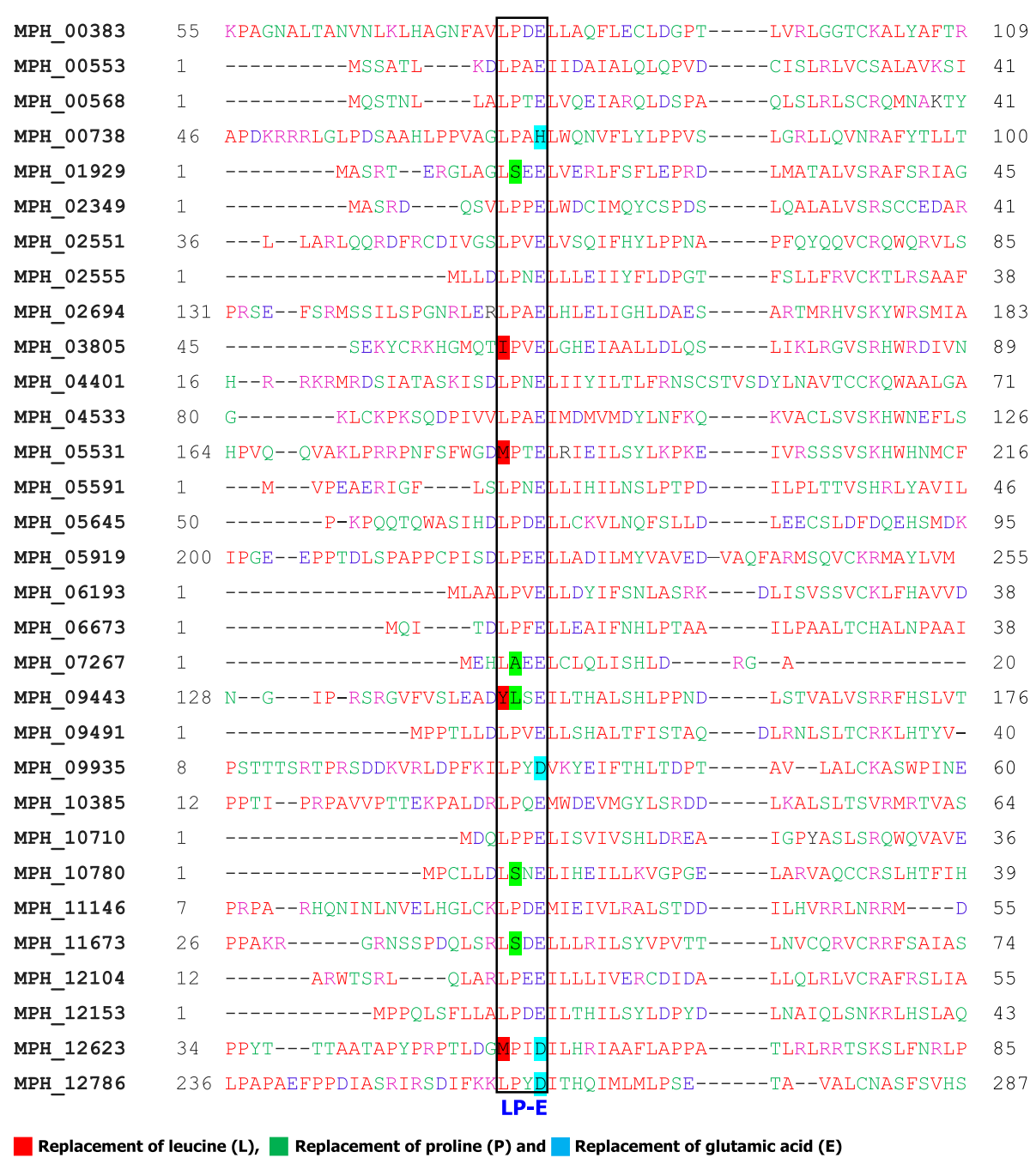

Fig. 3 Sequence alignment of F-box protein in the stem rot fungus M. phaseolina

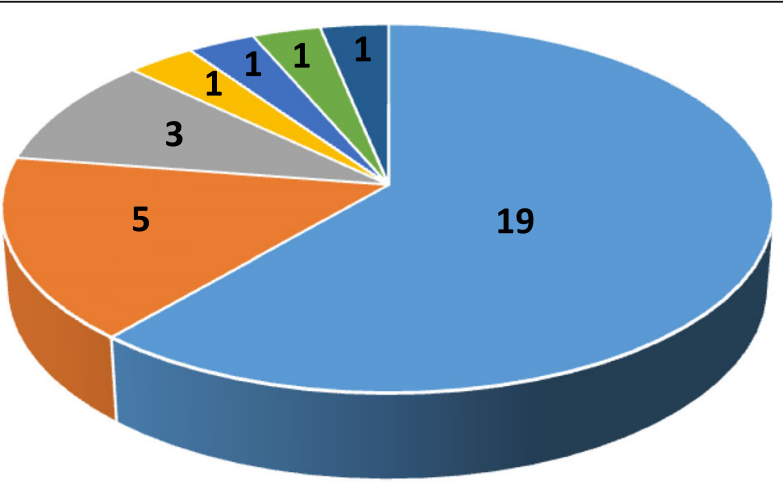

- Only F-box

- LRR

WD40

Ankyrin

- RNI-like domain

- Yccv-like domain

- ZnF-C2H2 domain

Fig. 4 Classification of F-box proteins in M. phaseolina. The number of F-box proteins were classified and shown in numbers 


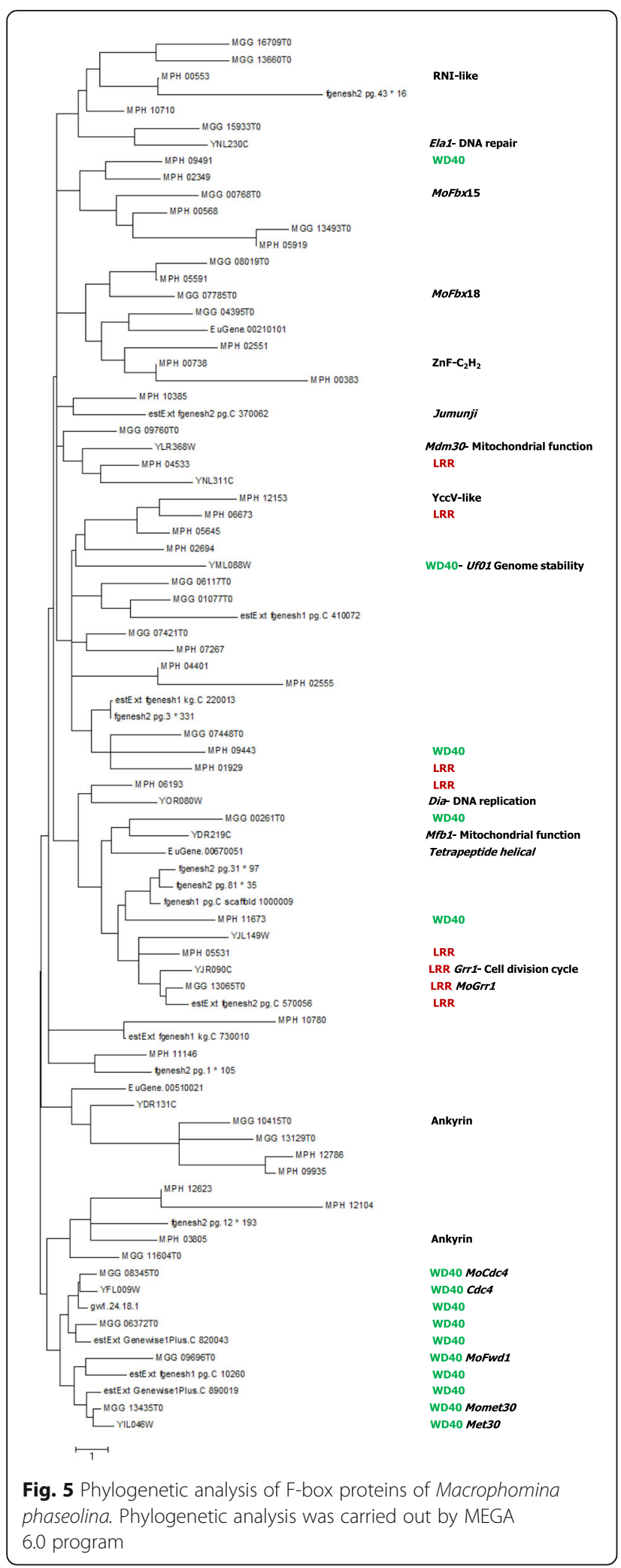

Fig. 5 Phylogenetic analysis of F-box proteins of Macrophomina phaseolina. Phylogenetic analysis was carried out by MEGA graminicola, Phanerochaete chrysosporium, and Aspergillus fumigatus (Table 1 and Fig. 6).

Comparative analysis of sequence alignment found the similar replacement of leucine $(\mathrm{L})$, proline $(\mathrm{P})$, and glutamic (E) are were also observed in the F-box protein of $M$. oryzae, S. cerevisiae, and B. graminis (Fig. 7). In yeast, $S$. cerevisiae, leucine $(\mathrm{L})$ and proline $(\mathrm{P})$ were not replaced; however, glutamic acid (E) was replaced by lysine (K), asparagine $(\mathrm{N})$, and leucine $(\mathrm{L})$. In $M$. oryzae, leucine (L) was replaced by the valine $(\mathrm{V})$, methionine $(\mathrm{M})$, and proline (P) was replaced by alanine (A). In B. graminis, proline (P) was only replaced by the serine (S). However, glutamic acid (E) was replaced by the aspartic acid (D), alanine (A), threonine $(\mathrm{T})$, and serine $(\mathrm{S})$. These results clearly indicate that point mutation is a common event in the living organisms.

SCF complex of F-box protein (skp2), was highly conserved in most selected biotrophic, hemibiotroph, necrotrophic, and symbiotic fungi (data not shown). This result suggests that phosphorylation process is common in all fungi for their growth and development including disease development. Interestingly, fungi contained comparatively more WD40 repeat than the plant F-box protein suggesting that fungi might require more WD40 for disease development (Table 3). Leucine-rich repeats (LRR) were highly present in plants than the fungi, indicating the importance of LRR for physical growth for survival. Abundance of ankyrin repeat in necrotrophic fungi gives hint that this repeat might be involved in the protein-protein interaction for disease development; however, this function has not been yet reported.

\section{Discussion}

Proteolysis is not only a common process for living organisms but also necessary for protein homeostasis for proper growth and development through the cell division cycle [34]. Several components have been reported to be involved in the proteolysis, and a novel motif called F-box is responsible for the ubiquitin-mediated proteolysis [14].

F-box proteins are highly species-specific, and there might be no relationship between the organism's genome size with their proportion. Protein number can be changed with the protein loss and gain in the genome $[19,35]$. In this research, fungal genome was found to contain different numbers of F-box proteins (Table 1); however, there was no distinct pattern for existing of Fbox proteins. The number of F-box proteins in fungal genome was comparatively much lower than the plant genome except symbiotic fungus Laccaria bicolor. Interestingly, the proportion of fungal F-box protein was much smaller than the proportion of plant F-box protein (data not shown). It seemed that fungi need 


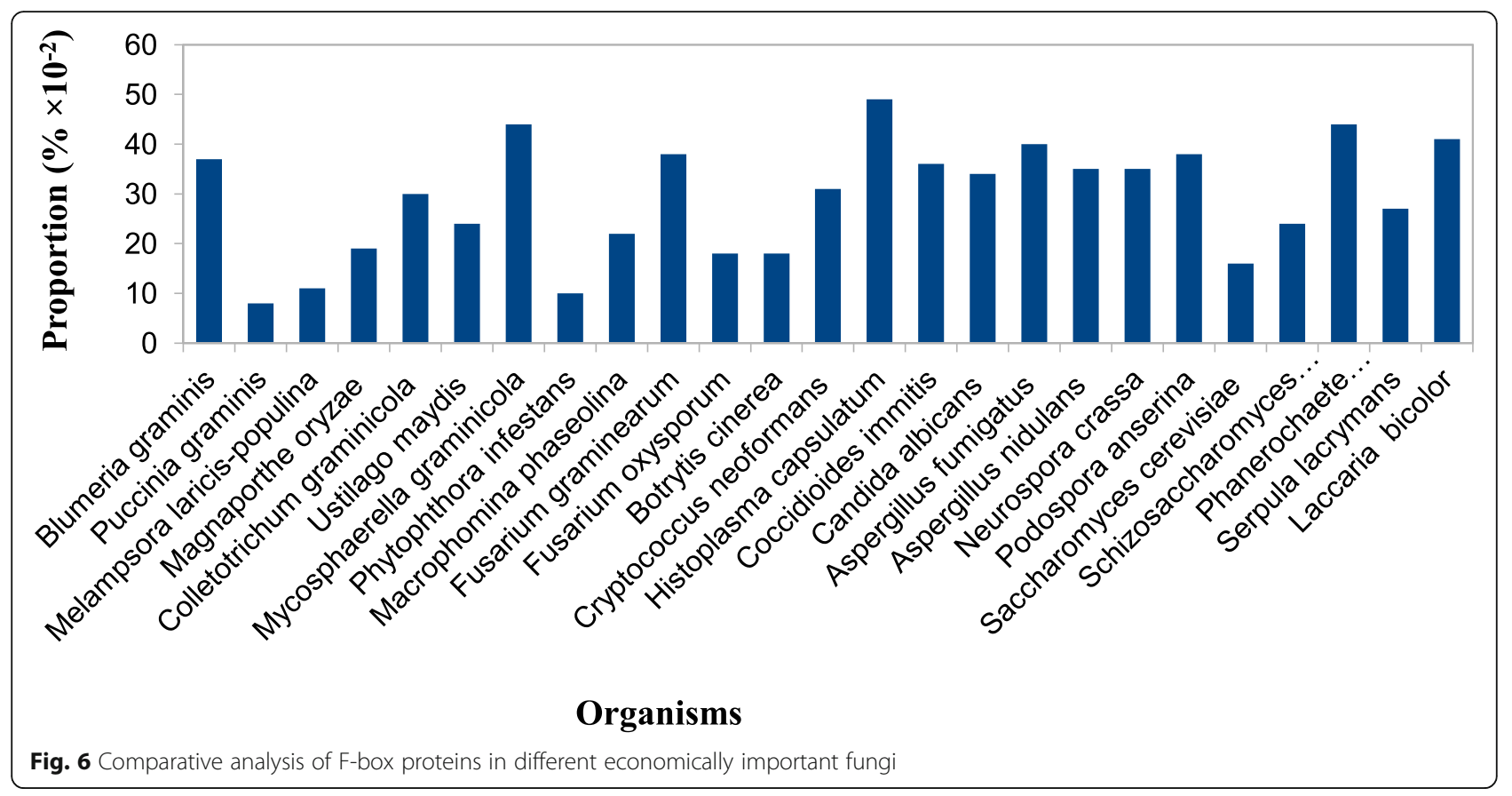

less number of F-box protein for their survival and disease development. This prediction is supported by the research where 24 F-box proteins were identified in rice blast fungus ( $M$. oryzae) genome; however, only three F-box proteins were found to be involved for full virulence [22]. Our identified F-box protein number might be varied because of the parameters (default) that we selected for our BLAST search against the F-box domain. It has been reported that BLAST is sensitive enough to identify the sequences from the remote homologous protein [36].

Exon-intron configuration of the F-box proteins has a distinct feature of having intron-less protein in many plant genomes [37]. Domain arrangement and composition can be resulted through shifting of exon-intron as well as insertion and/ or deletion of exon [19]. Stem rot fungal (M. phaseolina) F-box proteins contained $>50 \%$ of the total intron-less protein (Table 2). Although it is not clear how these proteins arisen in the stem rot fungus M. phaseolina genome, it seems to be originated through gene duplication or reverse transcription and integration. It has been reported that the number of genes in eukaryotic organisms can be duplicated through natural selection as well as by reverse transcription and then integration $[38,39]$. It was also reported that intron/exon structure of a subfamily had a strong structural relationship between the chickpea F-box proteins [13].

Leucine (L) and proline (P) were reported as the compulsory amino acids for the function of F-box protein in the living organisms [15]. However, leucine (L), proline
(P), and glutamic acid (E) were found to be replaced by several other amino acids in different F-box proteins in other four fungi (Fig. 3 and 7). These changes of amino acid might occur due to the single nucleotide substitution during the replication of DNA. It has been reported that single nucleotide replacement for another can occur during the replication of DNA [40, 41]. Amino acid replacement can also create mutational fore in living organisms [42]. It was hypothesized that alteration of amino acid in F-box proteins might lead to diverse functions in fungi. It also reports that due to the amino acid substitution, the similar gene showed diverse function in insulin delivery and reduction of enzymatic activity in human $[43,44]$.

Protein domains are the small units of evolution as well as the basic components of protein structure and function $[45,46]$. In general, fungi contain various numbers of domain compared with the other organisms [47]. Expansion of domain in the fungal genome occurred by domain duplication through recombination [48]. F-box proteins contain generally one or more variable proteinprotein interacting domain such as leucine-rich repeat (LRR), kelch repeat, WD40 repeat, and more for interaction with the target protein [49]. Domain analysis revealed that stem rot fungus contains a large fraction (61\%) of F-box proteins having only F-box domain (Fig. 4). It is highly likely that many of the F-box proteins might evolve into new ones in the stem rot fungus which had not undergone domain expansion yet or lost the domain for functional losses. In addition, conservation of F-box domain, skp2-like in 


\begin{tabular}{|c|c|c|c|c|}
\hline & $\begin{array}{l}\text { Gene ID } \\
\text { YDR131C } \\
\text { YML088W } \\
\text { YLR368W } \\
\text { fgenesh2_pg.3_\#_331 } \\
\text { MPH_01929 } \\
\text { MGG_11604 } \\
\text { MPH_12786 } \\
\text { YJR090C } \\
\text { estExt_fgenesh2_pg.C_570056 } \\
\text { YNL311C } \\
\text { MPH_11673 } \\
\text { MPH_02551 } \\
\text { MPH_05645 } \\
\text { MGG_16709 } \\
\text { fgenesh2_pg.31_\#_97 } \\
\text { fgenesh1_pg.C_scaffold_1000009 } \\
\text { fgenesh2_pg.12_\#_193 } \\
\text { MPH_02555 } \\
\text { MPH_12104 } \\
\text { MPH_00553 } \\
\text { MPH_10710 } \\
\text { estExt_fgenesh1_kg.C_730010 } \\
\text { MPH_06673 } \\
\text { MPH_05591 } \\
\text { MGG_07448 } \\
\text { estExt_fgenesh1_pg.C_410072 } \\
\text { estExt_fgenesh2_pg.C_370062 } \\
\text { MPH_12623 } \\
\text { MGG_06117 } \\
\text { YIL046W } \\
\text { estExt_Genewise1Plus.C_890019 } \\
\text { MPH_07267 } \\
\text { MGG_04395 } \\
\text { MPH_05919 } \\
\text { MPH_09491 } \\
\text { MGG_09696 } \\
\text { EuGene.00670051 } \\
\text { MGG_00768 } \\
\text { MGG_00261 } \\
\text { estExt_Genewise1P1us.C_820043 } \\
\text { YFL009W } \\
\text { gw1.24.18.1 } \\
\text { estExt_Genewise1Plus.C_890019 } \\
\text { MPH_07267 } \\
\text { MGG_04395 } \\
\text { MPH_05919 } \\
\end{array}$ & 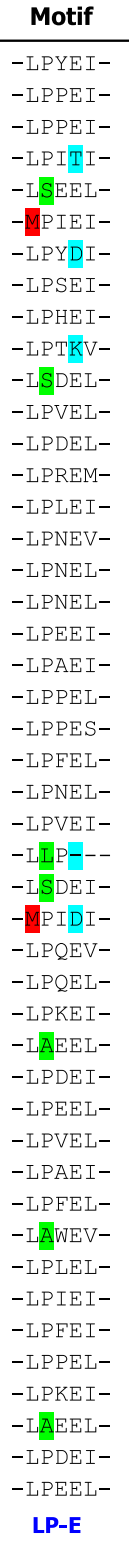 & $\begin{array}{l}\text { estExt_fgenesh1_pg.C_10260 } \\
\text { YOR080W } \\
\text { estExt_fgenesh1_kg.C_220013 } \\
\text { fgenesh2_pg.43_\#_16 } \\
\text { MPH_04533 } \\
\text { MGG_10415 } \\
\text { MPH_09935 } \\
\text { MGG_13065 } \\
\text { fgenesh2_pg.1_\#_105 } \\
\text { MPH_06193 } \\
\text { YDR219C } \\
\text { MPH_05531 } \\
\text { MGG_15933 } \\
\text { MGG_07421 } \\
\text { fgenesh2_pg.81_\#_35 } \\
\text { EuGene.00510021 } \\
\text { MPH_02349 } \\
\text { MPH_04401 } \\
\text { MGG_13129 } \\
\text { MPH_00568 } \\
\text { MPH_09443 } \\
\text { YJL149W } \\
\text { MGG_08019 } \\
\text { YNL230C } \\
\text { MGG_13660 } \\
\text { MPH_11146 } \\
\text { MPH_10780 } \\
\text { MGG_07785 } \\
\text { MPH_02694 } \\
\text { MGG_13435 } \\
\text { MPH_03805 } \\
\text { MPH_10385 } \\
\text { MGG_13493 } \\
\text { MPH_00738 } \\
\text { MPH_12153 } \\
\text { MGG_01077 } \\
\text { EuGene.00210101 } \\
\text { MGG_09760 } \\
\text { MGG_06372 } \\
\text { MPH_00383 } \\
\text { MGG_08345 } \\
\text { MPH_03805 } \\
\text { MPH_10385 } \\
\text { MGG_13493 } \\
\text { MPH_00738 } \\
\end{array}$ & $\begin{array}{l}\text {-LPEAL- } \\
\text {-LPIEI- } \\
\text {-LPITI- } \\
\text {-LSEEI- } \\
\text {-LPAEI- } \\
\text {-LPAEI- } \\
\text {-LPYDV- } \\
\text {-LPNEI- } \\
\text {-LPREI- } \\
\text {-LPVEL- } \\
\text {-LPLNL- } \\
\text {-MPTEL- } \\
\text {-LPAEI- } \\
\text {-LPPEI- } \\
\text {-LPTEV- } \\
\text {-LPLDLL } \\
\text {-LPPEL- } \\
\text {-LPNEL- } \\
\text {-LPLDI- } \\
\text {-LPTEL- } \\
\text { - YLSEI- } \\
\text {-LPDEL- } \\
\text {-LPNEI- } \\
\text {-VPPHL- } \\
\text {-LPQEL- } \\
\text {-LPDEM- } \\
\text {-LSNEL- } \\
\text {-LPHEL- } \\
\text {-LPAEL- } \\
\text {-LPAEI- } \\
\text {-IPVEL- } \\
\text {-LPQEM- } \\
\text {-LPDEV- } \\
\text {-LPAHL- } \\
\text {-LPDEI- } \\
\text {-VPGEL- } \\
\text {-LPDSV- } \\
\text {-LPTEI- } \\
\text {-LPDEL- } \\
\text {-LPDEL- } \\
\text {-LPAEL- } \\
\text {-IPVEL- } \\
\text {-LPQEM- } \\
\text {-LPEV- } \\
\text { LPAHL }\end{array}$ \\
\hline \multicolumn{5}{|c|}{ Replacement of leucine (L), $\square$ Replacement of proline (P) and $\quad$ Replacement of glutamic acid (E) } \\
\hline
\end{tabular}

fungi indicated the dependency of phosphorylation; however, proper-protein degradation relies on the multiple mechanisms [50].

Phylogenetic analysis not only shows the relation among the proteins but also indicate their evolutionary histories including climatic and geographical history on earth [51]. Each fungal F-box proteins were highly divergent in their sequences from others even though they had the similar functional domain (Fig. 5). It was expected that phylogenetically closely located proteins with the similar domain are involved in a similar function to interact with a similar substrate. However, same domain proteins might involve in different functions due to its point mutation in proteins sequences [52]. Similar event in domain shuffling for protein diversification was reported in rice where individual duplication was found [53]. In this paper, genome-wide F-box proteins have been identified in the jute stem rot fungus $M$. phaseolina that have been believed to be involved in protein degradation.

\section{Conclusion}

In this experiment, thirty-one F-box proteins from the jute stem rot fungus $M$. phaseolina were identified and analyzed. Based on the existence of different domains, all proteins 
Table 3 Comparison of leucine-rich repeat (LRR), WD40 (WD), and ankyrin (Ank) repeat in fungi

\begin{tabular}{|c|c|c|c|c|c|c|}
\hline Species & Kingdom & Phylum & Lifestyle & LRR & WD & Ank \\
\hline Blumeria graminis & Fungi & Ascomycota & Biotroph & 3 & 6 & 0 \\
\hline Puccinia graminis & Fungi & Basidiomycota & Biotroph & 0 & 6 & 0 \\
\hline Melampsora laricis-populina & Fungi & Basidiomycota & Biotroph & 1 & 5 & 0 \\
\hline Magnaporthe oryzae & Fungi & Ascomycota & Hemibiotroph & 1 & 6 & 1 \\
\hline Colletotrichum graminicola & Fungi & Ascomycota & Hemibiotroph & 2 & 6 & 0 \\
\hline Ustilago maydis & Fungi & Basidiomycota & Hemibiotroph & 1 & 7 & 0 \\
\hline Mycosphaerella graminicola & Fungi & Ascomycota & Hemibiotroph & 3 & 9 & 0 \\
\hline Phytophthora infestans & Chromista & Oomycota & Hemibiotroph & 0 & 0 & 1 \\
\hline Macrophomina phaseolina & Fungi & Ascomycota & Necrotroph & 5 & 3 & 1 \\
\hline Fusarium graminearum & Fungi & Ascomycota & Necrotroph & 3 & 8 & 1 \\
\hline Fusarium oxysporum & Fungi & Ascomycota & Necrotroph & 3 & 7 & 2 \\
\hline Botrytis cinerea & Fungi & Ascomycota & Necrotroph & 1 & 6 & 0 \\
\hline Cryptococcus neoformans & Fungi & Basidiomycota & Animal pathogen & 1 & 10 & 0 \\
\hline Histoplasma capsulatum & Fungi & Ascomycota & Animal pathogen & 3 & 9 & 0 \\
\hline Coccidioides immitis & Fungi & Ascomycota & Animal pathogen & 2 & 7 & 4 \\
\hline Candida albicans & Fungi & Ascomycota & Animal pathogen & 0 & 3 & 0 \\
\hline Aspergillus fumigatus & Fungi & Ascomycota & Animal pathogen & 2 & 8 & 2 \\
\hline Aspergillus nidulans & Fungi & Ascomycota & Saprotroph & 2 & 10 & 2 \\
\hline Neurospora crassa & Fungi & Ascomycota & Saprotroph & 2 & 7 & 2 \\
\hline Podospora anserina & Fungi & Ascomycota & Saprotroph & 2 & 8 & 3 \\
\hline Saccharomyces cerevisiae & Fungi & Ascomycota & Saprotroph & 0 & 3 & 0 \\
\hline Schizosaccharomyces pombe & Fungi & Ascomycota & Saprotroph & 1 & 7 & 0 \\
\hline Phanerochaete chrysosporium & Fungi & Basidiomycota & Saprotroph & 1 & 6 & 0 \\
\hline Serpula lacrymans & Fungi & Basidiomycota & Saprotroph & 0 & 7 & 0 \\
\hline Laccaria bicolor & Fungi & Basidiomycota & Symbiotic & 0 & 11 & 0 \\
\hline Arabidopsis thaliana & Viridiplantae & Streptophyta & N/A & 29 & 2 & ND \\
\hline Oryza sativa japonica & Viridiplantae & Streptophyta & N/A & 61 & 2 & ND \\
\hline Cicer arietinum & Viridiplantae & Streptophyta & N/A & 39 & 4 & ND \\
\hline
\end{tabular}

Note: $L R R$ leucine-rich repeat, WD WD40 domain, Ank ankyrin repeat, ND not determined

were categorized in five groups. Large group (61\%) consists of F-box domain alone; however, leucine-rich repeat (LRR) and WD40-containing group were in the second and third largest group, respectively. Single nucleotide substitution resulted in leucine $(\mathrm{L})$, proline $(\mathrm{P})$, and glutamic acid $(\mathrm{E})$ in several F-box proteins in different fungi. Phylogenetic tree revealed that proteins from the same group are highly diverse from each other indicating the diverse functions of F-box proteins in fungi. These results provide an essential understanding of F-box protein in $M$. phaseolina and constitute a strong foundation for further investigation in the regulation of fungal virulence, which may lead to novel approaches in developing new antifungal agents.

\section{Abbreviations}

DNA: Deoxyribonucleic acid; ATP: Adenosine triphosphate; SCF: Skp, Cullin and F-box containing; Grr1: Glucose repression resistant 1; BARJ: Basic and Applied Research on Jute Project; NCBI: National Center for Biotechnology
Information; CFGP: Comparative fungal genomic platform; GFF: General feature format; MEGA: Molecular Evolutionary Genetics Analysis; NJ: Neighbor-joining; LRR: Leucine-rich repeat; ER: Endoplasmic reticulum

\section{Supplementary Information}

The online version contains supplementary material available at https://doi. org/10.1186/s43141-021-00143-0.

Additional file 1: Table S1. Identified F-box proteins in the stem rot fungus Macrophomina phaseolina.

Additional file 2: Table S2. BLAST search result of F-box protein of Macrophomina phaseolina.

Additional file 3: Table S3. BLAST2GO analysis of Macrophomina phaseolina F-box proteins.

Additional file 4: Figure S1. Exon-intron structure and length F-box protein in stem rot fungus $M$. phaseolina.

\section{Acknowledgements}

Authors are thankful to Basic and Applied Research on Jute Project, Bangladesh Jute Research Institute for pursuing research activities. 


\section{Authors' contributions}

MAS, MWU, and MSI designed the study. MAS, KKB, QMMH, and MZT performed the experiments and analyzed the data. MAS wrote the manuscript. MUW, KKB, and MSI edited and finalized the manuscript and supervised the overall study. The authors read and approved the final manuscript.

\section{Funding}

Not applicable.

\section{Availability of data and materials}

All the protein sequences are available in the NCBI database.

\section{Declarations}

\section{Ethics approval and consent to participate}

Not applicable.

\section{Consent for publication}

Not applicable

\section{Competing interests}

The authors declare that they have no conflicts of interest in the publication.

Received: 10 December 2020 Accepted: 11 March 2021

Published online: 24 March 2021

\section{References}

1. Liu TB, Wang Y, Stukes K, Chen Q, Casadevall A, Xue C (2011) The F-box protein Fbp1 regulates sexual reproduction and virulence in Cryptococcus neoformans. Eukaryot Cell 10(6):791-802. https://doi.org/10.1128/EC. 00004-11

2. Jain M, Nijhawan A, Arora R, Agarwal P, Roy S, Sharma P, Kapoor S, Tyagi AK, Khurana JP (2007) F-box proteins in rice. Genome-wide analysis, classification, temporal and spatial gene expression during panicle and seed development, and regulation by light and abiotic stress. Plant Physiol 143(4):1467-1483. https://doi.org/10.1104/pp.106.091900

3. Dunlop DS (1983) Protein turnover in brain synthesis and degradation. In: Handbook of Neurochemistry, pp 25-63. https://doi.org/10.1007/978-1-4 899-4555-6_2

4. Ardejani MS, Powers ET, Kelly JW (2017) Using cooperatively folded peptides to measure interaction energies and conformational propensities. Acc Chem Res 50(8):1875-1882. https://doi.org/10.1021/acs.accounts.7b00195

5. Branden C, Tooze J (1999) Introduction to protein structure. Garland Publication, New York

6. Lodish H, Berk A, Matsudaira P, Kaiser CA, Krieger M, Scott MP, Zipurksy SL, Darnell J (2004) Molecular cell biology, 5th edn. WH Freeman and Company, New York

7. Van Holde KE, Mathews CK (1996) Biochemistry. Benjamin/Cummings Pub. Co., Inc., Menlo Park

8. Voet D, Voet JG (2004) Biochemistry, vol 1, 3rd edn. Wiley, Hoboken

9. Han YK, Kim MD, Lee SH, Lee YW (2007) A novel F-box protein involved in sexual development and pathogenesis in Gibberella zeae. Mol Microbiol 63(3):768-779. https://doi.org/10.1111/j.1365-2958.2006.05557.x

10. Lecker SH, Goldberg AL, Mitch WE (2006) Protein degradation by the ubiquitin-proteasome pathway in normal and disease states. J Am Soc Nephrol 17(7):1807-1819. https://doi.org/10.1681/ASN.2006010083

11. Baehrecke EH (2002) Autophagy: dual roles in life and death. Nat Rev Mol Cell Biol 6:505-510

12. Glickman MH, Ciechanover A (2002) The ubiquitin-proteasome proteolytic pathway: destruction for the sake of construction. Physiol Rev 82(2):373428. https://doi.org/10.1152/physrev.00027.2001

13. Gupta S, Garg A, Kant C, Bhatia S (2015) Genome-wide survey and expression analysis of F-box genes in chickpea. BMC Genomics 16(1):67. https://doi.org/10.1186/s12864-015-1293-y

14. Kumar A, Paietta JV (1980) An additional role for the F-box motif: gene regulation within the Neurospora crassa sulfur control network. Proc Natl Acad Sci U S A 95:2417-2422

15. Jonkers W, Rep M (2009) Lessons from fungal F-box proteins. Eukaryot Cell 8(5):677-695. https://doi.org/10.1128/EC.00386-08
16. Clifford R, Lee MH, Nayak S, Ohmachi M, Giorgini F, Schedl T (2000) FOG-2, a novel F-box containing protein, associates with the GLD-1RNA binding protein and directs male sex determination in the C. elegans hermaphrodite germline. Development 127(24):5265-5276

17. Galan JM, Wiederkehr A, Seol JH, Haguenauer-Tsapis R, Deshaies RJ, Riezman H, Peter M (2001) Skp1p and the F-box protein Rcylp formnonSCF complex involved in recycling of the SNARE Snc1p in yeast. Mol Cell Biol 21(9):3105-3117. https://doi.org/10.1128/MCB.21.9.3105-3117.2001

18. Kim J, Kim JH, Lee SH, Kim DH, Kang HY, Bae SH, Pan ZQ, Seo YS (2002) The novel human DNA helicase hFBH1 is an F-box protein. J Biol Chem 277(27): 24530-24537. https://doi.org/10.1074/jbc.M201612200

19. Xu G, Ma H, Nei M, Kong H (2009) Evolution of F-box genes in plants: different modes of sequence divergence and their relationships with functional diversification. PNAS 106(3):835-840. https://doi.org/10.1073/pnas. 0812043106

20. Guo M, Gao F, Zhu X, Nie X, Gao Z (2015) MoGrr1, a novel F-box protein, is involved in conidiogenesis and cell wall integrity and is critical for the full virulence of Magnaporthe oryzae. Appl. Microb Biotechnol 99(19):8075-8088. https://doi.org/10.1007/s00253-015-6820-x

21. Prakash C, Manjrekar J, Chattoo BB (2016) Skp1, a component of E3 ubiquitin ligase, is necessary for growth, sporulation, development and pathogenicity in rice blast fungus (Magnaporthe oryzae). Mol Plant Pathol 17(6):903-919. https://doi.org/10.1111/mpp.12336

22. Shi HB, Chen N, Zhu XM, Liang S, Li L, Wang JY, Lu JP, Lin FC, Liu XH (2019) F-box proteins MoFwd1, MoCdc4 and MoFbx15 regulate development and pathogenicity in the rice blast fungus Magnaporthe oryzae. Environ Microbiol 21(8):3027-3045. https://doi.org/10.1111/1462-2920.14699

23. Atir-Lande A, Gildor T, Kornitzer D (2005) Role for the SCFCDC4 ubiquitin ligase in Candida albicans morphogenesis. Mol Biol Cell 16(6):2772-2785. https://doi.org/10.1091/mbc.e05-01-0079

24. Krappmann S, Jung N, Medic B, Busch S, Prade RA, Braus GH (2006) The Aspergillus nidulans F-bx protein GrrA links SCF activity to meiosis. Mol Microbiol 61(1):76-88. https://doi.org/10.1111/j.1365-2958.2006.05215.x

25. Mitsiades CS, Mitsiades N, Hideshima T, Richardson PG, Anderson KC (2009) Proteasome inhibitors as therapeutics. Essays Biochem 41:205-218 Murray, R. F. H. W. Harper, D. K. Granner, P. A. Mayes, and Rodwell, V. W. 2006. Harper's Illustrated Biochemistry. New York: Lange Medical Books/McGraw-Hil

26. GOB (1995) Bangladesh hand book. External publicity wing, Ministry of information, Government of Bangladesh.

27. Bangladesh Bureau of Statistics (BBS) (2011) Yearbook of agriculture statistics of Bangladesh. Bangladesh Bureau of Statistics, Statistic Division, Ministry of planning, Government of the People's Republic of Bangladesh. 22nd edition.

28. Mamun MA, Shamsi S, Bashar MA (2016) Estimation of interrelationships among some quality factors of jute seeds. Dhaka Uni J Biol Sci 25(10):9-17. https://doi.org/10.3329/dujbs.v25i1.28485

29. Islam MS, Haque MD, Islam MM, Emdad EM, Halim A, Hossen OMM, Hossain MZ, Ahmed B, Rahim S, Rahman MS, Alam MD, Hou S, Wan X, Saito JA, Alam M (2012) Tools to kill: genome of one of the most destructive plant pathogenic fungi Macrophomina phaseolina. BMC Genomics 13(1):493. https://doi.org/10.1186/1471-2164-13-493

30. Choi J, Cheong K, Jung K, Jeon J, Lee GW, Kang S, Kim S, Lee YW, Lee YH (2013) CFGP 2.0: a versatile web-based platform for supporting comparative and evolutionary genomics of fungi and Oomycetes. Nucleic Acids Res 41(D1):D714-D719. https://doi.org/10.1093/nar/gks1163

31. Kuroda H, Takahashi N, Shimada H, Seki M, Shinozaki V, Matsui M (2002) Classification and expression analysis of Arabidopsis F-box-containing proteins genes. Plant Cell Physiol 43(10):1073-1085

32. Horton P, Park KJ, Obayashi T, Fujita N, Harada H, Adams-Collier CJ (2007) WoLF PSORT: protein localization predictor. Nucleic Acids Res 35(2):1-3

33. Tamura K, Peterson D, Peterson N, Stecher G, Nei M, Kumar S (2011) MEGA5: molecular evolutionary genetics analysis using maximum likelihood, evolutionary distance, and maximum parsimony methods. Mol Biol Evol 28(10):2731-2739. https://doi.org/10.1093/molbev/msr121

34. King RW, Deshaies RJ, Peters JM, Kirschner (1996) How preoteolysis drives the cell cycle. Science 274(5293):1652-1659. https://doi.org/10.1126/ science.274.5293.1652

35. Hua Z, Zou C, Shiu SH, Vierstra RD (2011) Phylogenetic comparison of F-box (FBX) gene superfamily within the plant kingdom reveals divergent evolutionary histories indicative of gnomic drift. PLoS One 6(1):e16219. https://doi.org/10.1371/journal.pone.0016219 
36. Sadat MA, Jeon J, Mir AA, Kim S, Choi J, Lee YH (2014) Analysis of in planta expressed orphan genes in the rice blast fungus Magnaporthe oryzae. Plant Pathol J 30(4):367-374. https://doi.org/10.5423/PPJ.OA.08.2014.0072

37. Yang X, Kalluri UC, Jawdy S, Gunter LE, Yin T, Tschaplinski TJ, Weston DJ, Ranjan P, Tuskan GA (2008) F-box gene family is expended in herbaceous and annual plants relative to woody perennial plants. Plant Physiol 148(3): 1189-1200. https://doi.org/10.1104/pp.108.121921

38. Kaessmann $\mathrm{H}$, Vinckenbosch N, Long M (2009) RNA-based gene duplication: mechanistic and evolutionary insights. Nat Rev Genet 10(1):19-31. https:// doi.org/10.1038/nrg2487

39. Powell AJ, Conant GC, Brown DE, Carbone I, Dear RA (2008) Altered patterns of gene duplication and differential gene gain and loss in fungal pathogens. BMC Genomics 9(1):147. https://doi.org/10.1186/14 71-2164-9-147

40. Kunkel TA (1992) Biological asymmetries and the fidelity of eukaryotic DNA replication. Bioassays 14(5):303-308. https://doi.org/10.1002/bies.950140503

41. Stillman B (1994) Smart machines at the DNA-replication fork. Cell 78(5): 725-728. https://doi.org/10.1016/S0092-8674(94)90362-X

42. Blazej P, Mackiewicz D, Grabinska M, Wnetrzak M, Pawel M (2017) Optimization of amino acid replacement costs by mutational pressure in bacterial genomes. Sci Res 7:1061

43. Sim E, Fullam E, Wakefield L (2010) Arylamine N-acetyltransferases. Comp Toxico:385-412. https://doi.org/10.1016/B978-0-08-046884-6.00419-X

44. Sonia TA, Sharma CP (2014) Oral insulin delivery-challenges and strategies. Oral Delivery Insulin:113-168. https://doi.org/10.1533/9781908818683.113

45. Buljan M, Frankish A, Bateman A (2010) Quantifying the mechanisms of domain gain in animal proteins. Genome Biol 11(7):R74. https://doi.org/1 0.1186/gb-2010-11-7-r74

46. Murzin AG, Brenner SE, Hubbard T, Chothia C (1995) SCOP: a structural classification of proteins database for the investigation of sequences and structures. J Mol Biol 247(4):536-540. https://doi.org/10.1016/50022-283 6(05)80134-2

47. Zhang X, Gou M, Chang-Jun L (2013) Arabidopsis kelch repeat F-box proteins regulate phenylpropanoid biosynthesis via controlling the turnover of phenylalanine ammonia-lyase. Plant Cell 25(12):4994-5010. https://doi. org/10.1105/tpc.113.119644

48. Bjorklund AK, Ekman D, Elofsson A (2006) Expansion of protein domain repeats. PLoS Comput Biol 2(8):e114. https://doi.org/10.1371/ journal.pcbi.0020114

49. Bai C, Richman R, Elledge SJ (1994) Human cyclin F. EMBO J 13(24):60876098. https://doi.org/10.1002/j.1460-2075.1994.tb06955.x

50. Skaar JR, Pagan JK, Michele P (2013) Mechanisms and function of substrate recruitment by F-box proteins. Nat Rev Mol Cell Biol 14(6):369-381. https:// doi.org/10.1038/nrm3582

51. Uncu AO, Uncu AT, Celik I, Doganlar S, Frary A (2015) A primer to molecular phylogenetic analysis in plants. Crit Rev Plant Sci 34(4):454-468. https://doi. org/10.1080/07352689.2015.1047712

52. Cannon SB, Mitra A, Baumgarten A, Young ND, May G (2004) The roles of segmental and tandem gene duplication in the evolution of large gene families in Arabidopsis thaliana. BMC Plant Biol 4(1):10. https://doi.org/10.11 86/1471-2229-4-10

53. Yu J, Lin W, Li S, Li H, Zhou J, Ni P, Dong W, Hu S, Zeng C, Zhang J, Zhang $Y$ et al (2005) The genomes of Oryza sativa: a history of duplication. PLoS Biol 3(2):e38. https://doi.org/10.1371/journal.pbio.0030038

\section{Publisher's Note}

Springer Nature remains neutral with regard to jurisdictional claims in published maps and institutional affiliations.

\section{Submit your manuscript to a SpringerOpen ${ }^{\circ}$ journal and benefit from:}

- Convenient online submission

- Rigorous peer review

- Open access: articles freely available online

- High visibility within the field

- Retaining the copyright to your article

Submit your next manuscript at $\boldsymbol{\nabla}$ springeropen.com 